\title{
IS THE HEART A SOURCE FOR ELEVATED CIRCULATING ENDOTHELIN LEVELS DURING AORTA-CORONARY ARTERY BYPASS GRAFTING SURGERY IN HUMAN BEINGS?
}

David Hasdai, $\mathrm{MD}^{\mathrm{a}}$

Eldad Erez, $\mathrm{MD}^{\mathrm{b}}$

Irit Gil-Ad, PhD $^{\mathrm{c}}$

Ehud Raanani, MD ${ }^{b}$

Samuel Sclarovsky, $\mathrm{MD}^{\mathrm{a}}$

Yaakov Barak, MD ${ }^{b}$

Jaqueline Sulkes, MSc ${ }^{d}$

Bernardo A. Vidne, MD $^{\mathrm{b}}$
Reports have shown increased systemic levels of endothelins during coronary artery bypass grafting in human beings. It was not known whether increased endothelin levels during coronary artery bypass grafting reflect a general systemic response to the surgical procedure or increased myocardial production of endothelins in response to ischemia and reperfusion. We therefore measured endothelin levels in the right atrium and proximal aorta of 15 patients undergoing coronary artery bypass grafting for anginal syndrome immediately before aortic crossclamping and again after cessation of cardiopulmonary bypass. In five patients, we also measured coronary sinus levels of endothelins during cardiopulmonary bypass circulation. We found that endothelin levels were elevated throughout the surgical procedure. Right atrial endothelin levels were significantly elevated after cessation of cardiopulmonary bypass circulation with respect to values immediately before aortic crossclamping $(11.1 \pm 3.1$ vs $14.2 \pm 3.7$ $\mathrm{pg} / \mathrm{ml}, p=0.008$ ), whereas endothelin levels in the proximal aorta did not rise significantly $(10.5 \pm 2.3$ vs $11.6 \pm 2.4 \mathrm{pg} / \mathrm{ml}, p>0.5)$. Coronary sinus endothelin levels tended to decline temporarily during cardiopulmonary bypass circulation $(11.1 \pm 2.1 \mathrm{pg} / \mathrm{ml}$ before aortic crossclamping, $7.9 \pm 1.9$ 1 minute after release of aortic crossclamp, and $9.9 \pm 2.1 \mathrm{pg} / \mathrm{ml}$ after release of partial aortic crossclamping, $p=0.06$ ). We conclude that the rise in right atrial endothelin levels during coronary artery bypass grafting reflects systemic production and secretion of endothelins, probably by vasculature or organs distal to the proximal aorta, and is not the result of increased myocardial production and secretion of endothelins. ( $J$ Thorac Cardiovasc Surg 1996;112:531-6)
T he endothelin family, known for its potent vasoconstrictive activity, ${ }^{1}$ consists of three structurally and pharmacologically distinct 21-amino acid isopeptides, ET-1, ET-2, and ET-3, each produced by a different gene. ${ }^{2}$ Although endothelins were thought to be produced solely by endothelial cells, they have been shown to be produced by other cell types, ${ }^{3-8}$ including cardiac myocytes. ${ }^{9}$ ET- 1 is the

From the Departments of Cardiology ${ }^{\mathrm{a}}$ and Cardiothoracic Surgery, ${ }^{\mathrm{b}}$ the Pediatric Endocrinology Laboratory, ${ }^{\mathrm{c}}$ and the Epidemiology Unit, ${ }^{d}$ Sackler School of Medicine, Tel Aviv University, and Beilinson Medical Center, Petah Tikva, Israel.

Received for publication July 13, 1995; revisions requested Sept. 13, 1995; revisions received Dec. 29, 1995; accepted for publication Jan. 15, 1996.

Address for reprints: Samuel Sclarovsky, MD, Department of Cardiology, Beilinson Medical Center, Petah-Tikva, Israel 49100.

Copyright $\mathbb{C} 1996$ by Mosby-Year Book, Inc.

$0022-5223 / 96 \$ 5.00+0 \quad \mathbf{1 2 / 1 / 7 1 9 1 6}$ most abundant and biologically active of the endothelin isopeptides in the human heart. ${ }^{10}$

During acute myocardial infarction, circulating endothelin levels consistently are increased, especially when the clinical course is complicated by heart failure. In contrast, during other forms of myocardial ischemia, such as stable and unstable angina, circulating endothelin levels remain unaltered in most clinical studies. ${ }^{11}$ In contrast to the relatively consistent results attained in human beings, endothelin levels in various animal models of myocardial ischemia and infarction have been reported to be increased, decreased or unchanged. ${ }^{11}$

Reports have shown increased systemic (arterial) levels of immunoreactive endothelins during coronary artery bypass grafting (CABG) in human beings. ${ }^{12-15}$ Anesthesia and surgical procedures may themselves elevate plasma levels of endothelins, ${ }^{16,17}$ so increased endothelin levels during CABG in human beings may reflect a general systemic response 
Table I. Stages for blood sampling

\begin{tabular}{lllll}
\hline & \multicolumn{4}{c}{ Surgical stage } \\
\cline { 2 - 4 } & 1 & 2 & 3 & 4 \\
\hline Group A $(n=10)$ & & & & \\
Aortic root & $\mathrm{X}$ & & & $\mathrm{X}$ \\
Right atrium & $\mathrm{X}$ & & & $\mathrm{X}$ \\
Group B $(n=5)$ & & & & \\
Aortic root & $\mathrm{X}$ & $\mathrm{X}$ & $\mathrm{X}$ & $\mathrm{X}$ \\
Right atrium & $\mathrm{X}$ & $\mathrm{X}$ & $\mathrm{X}$ & $\mathrm{X}$ \\
Coronary sinus & $\mathrm{X}$ & $\mathrm{X}$ & $\mathrm{X}$ &
\end{tabular}

Stage 1, Immediately before aortic crossclamping; Stage 2, 1 minute after release of aortic crossclamping; Stage 3, release of partial aortic crossclamping; Stage 4, immediately after CPB.

to the surgical procedure or myocardial production of endothelins in response to ischemia and reperfusion. ${ }^{18-19}$ This study was undertaken (1) to characterize the kinetics of circulating endothelin levels during $C A B G$ and (2) to determine the contribution of the heart to changes in circulating endothelin levels during $C A B G$ in human beings.

\section{Methods}

Patients. The study population consisted of 15 patients undergoing $\mathrm{CABG}$ at Beilinson Medical Center on an elective basis for angina pectoris. Patients with chronic renal failure (serum creatinine $>1.4 \mathrm{mg} / \mathrm{dl}$ ), hepatic cirrhosis, scleroderma, pulmonary hypertension, uncontrolled hypertension, recent myocardial infarction, or severe congestive heart failure (ejection fraction $<0.35$ or New York Heart Association functional class III or IV) were excluded because these conditions have themselves been found to be associated with elevated plasma levels of endothelins. ${ }^{20-26}$ Patients were informed of the surgical procedure by the attending physician, after which they signed informed consent to undergo operation.

Surgical protocol. Each patient was anesthetized with intravenous injections of midazolam $(0.05 \mathrm{mg} / \mathrm{kg}$ body weight) and fentanyl (30 to $50 \mu \mathrm{g} / \mathrm{kg}$ body weight). Muscular relaxation was obtained with pancuronium bromide $(0.2 \mathrm{mg} / \mathrm{kg}$ body weight $)$. Patients were mechanically ventilated (Narcomed 2B, N.A.D., Inc., Telford, Pa.) with adjustments in parameters to maintain normocapnia on frequent arterial blood gas measurements. The radial artery and internal jugular vein were cannulated for blood pressure and central venous pressure monitoring, respectively. Heart rate was monitored by surface electrocardiography. The mediastinum was exposed by a median sternotomy. Intravenous heparin (3 $\mathrm{mg} / \mathrm{kg}$ body weight) was administered before cannulas were inserted for cardiopulmonary bypass (CPB), with repeated injections as necessary to maintain activated clotting time at longer than 400 seconds. Hypothermic $\left(28^{\circ} \mathrm{C}\right)$ nonpulsatile CPB was established through a cannula in the ascending aorta and a cannula in the right atrium (two-stage cannula) for venous return. A disposable membrane oxygenator (Polystan, Copenhagen, Denmark) with polyvinyl chloride tubing was used with a roller pump. The extracorpeal circuit consisted of Hartman's solution, and the hematocrit value was maintained at $25 \% \pm 1 \%$ during CPB. A small amount of pulmonary perfusion persisted and was returned to the heart-lung machine through aortic root aspiration. Grafting was performed during a single period of aortic occlusion with cold $\left(4^{\circ} \mathrm{C}\right)$ cardioplegic solution injected retrogradely into the coronary arteries through the aortic root and the coronary sinus. In group A (the first 10 patients), the cardioplegic solution consisted of Plasma-Lyte solution and $100 \mathrm{mg}$ lidocaine, $40 \mathrm{mg}$ papaverine, $12 \mathrm{mEq}$ potassium, and $500 \mathrm{mg}$ methylprednisolone. In group B (five later patients), blood cardioplegia was used. Induction blood cardioplegic solution (consisting of $400 \mathrm{mg}$ lidocaine, $80 \mathrm{mg}$ papaverine, 60 $\mathrm{mEq}$ potassium, $500 \mathrm{mg}$ methylprednisolone [SoluMedrol] $2.5 \mathrm{gm}$ glucose, $5 \mathrm{gm}$ magnesium ion, and $15 \mathrm{mEq}$ sodium bicarbonate in $1000 \mathrm{ml}$ saline solution) was given antegradely (aortic root) and retrogradely (coronary sinus) simultaneously. The rate of induction of blood cardioplegia (blood/crystalloid dilution factor of 4:1) was 200 to $250 \mathrm{ml} / \mathrm{min}$, with a coronary sinus pressure limit of $40 \mathrm{~mm} \mathrm{Hg}$. Every 20 to 30 minutes thereafter, cardioplegia ( $400 \mathrm{mg}$ lidocaine, $80 \mathrm{mg}$ papaverine, $12 \mathrm{mEq}$ potassium, $2.5 \mathrm{gm}$ glucose, $5 \mathrm{gm}$ magnesium ion and $15 \mathrm{mEq}$ sodium bicarbonate) was given retrogradely. In both groups (A and $B$ ), the cardioplegic solution partially perfused the lungs and was collected outside the extracorpeal circuit.

Blood samples. For all patients (groups A and B), arterial and mixed venous blood samples were drawn from indwelling cannulas in the ascending aorta (proximal to the connection of CPB circuit to aorta) and the right atrium, respectively. For patients in group B, blood samples were also drawn from a cannula in the coronary sinus. The stages at which blood samples were drawn for each group are depicted in Table I. A $5 \mathrm{ml}$ sample of blood was placed in a precooled tube containing ethylene diamine tetraacetate and $100 \mathrm{KIU}$ aprotonin (Trasylol, Bayer AG, Leverkusen, Germany). All tubes were immersed in ice and later centrifuged at $3000 \mathrm{~g}$ for 15 minutes at $4^{\circ} \mathrm{C}$. The supernatant from each tube was then stored in a vial at minus $70^{\circ} \mathrm{C}$ for subsequent biochemical analysis.

ET assay. Plasma ET levels were determined with a commercial kit (Assay Kit 40-6026) purchased from Nichols Institute Diagnostics (The Netherlands). In short, preliminary extraction of $\mathrm{ET}$ was performed on silica $\mathrm{C}_{18}$ (Nichols Institute) cartridges after acidification of plasma, followed by radioimmunoassay with an iodine 125 tracer and a polyclonal rabbit antibody. Endothelins were further separated by a second antibody solid-phase system and centrifugation. A standard curve was prepared and all results were read from the curve. The assay was performed by the same investigator (I. G.) in duplicate for each sample. The kit has a reported sensitivity of $2 \mathrm{pg} / \mathrm{ml}$ and specifities and cross-reactivities of $100 \%$ for ET-1, $67 \%$ for ET-2, 84\% for ET-3, 2.6\% for big ET-1, 5.3\% for big ET-2, and $0.2 \%$ for big ET-3. Mean value reported for normal control samples with this assay is $2.9 \mathrm{pg} / \mathrm{ml}$. In our laboratory, we found mean values of $2.6 \pm 0.7 \mathrm{pg} / \mathrm{ml}$ for a group of 10 normal volunteers.

Statistics. Results are presented as mean ( \pm standard deviation). The Wilcoxon signed rank test was used to 
Table II. Demographic, clinical, and procedural data

\begin{tabular}{rccccccccc}
\hline No. & Group & $\begin{array}{c}\text { Age } \\
(y)\end{array}$ & Sex & MI & HTN & DM & $\begin{array}{c}X \\
\text { (min) }\end{array}$ & $\begin{array}{c}C P B \\
\text { (min) }\end{array}$ & Grafts \\
\hline 1 & A & 60 & M & + & - & + & 54 & 80 & 4 \\
2 & A & 67 & F & + & + & - & 27 & 47 & 2 \\
3 & A & 69 & M & - & - & - & 48 & 75 & 2 \\
4 & A & 66 & F & + & + & - & 48 & 82 & 3 \\
5 & A & 70 & F & - & - & - & 45 & 78 & 2 \\
6 & A & 65 & M & - & - & - & 47 & 73 & 2 \\
7 & A & 46 & M & + & + & - & 61 & 103 & 4 \\
8 & A & 61 & F & - & - & + & 83 & 143 & 4 \\
9 & A & 65 & F & + & - & + & 45 & 66 & 3 \\
10 & A & 61 & M & + & - & - & 47 & 75 & 3 \\
11 & B & 72 & F & - & + & + & 83 & 143 & 4 \\
12 & B & 62 & M & + & - & + & 50 & 72 & 3 \\
13 & B & 47 & M & - & - & + & 76 & 132 & 4 \\
14 & B & 59 & M & + & + & - & 96 & 180 & 5 \\
15 & B & 69 & M & + & + & - & 68 & 122 & 4 \\
\hline
\end{tabular}

$M I$, History of myocardial infarction; $H T N$, history of hypertension; $D M$, history of diabetes mellitus; $X$, aortic crossclamp time.

compare endothelin levels. All tests were two-tailed, and $p$ values no greater than 0.05 were considered significant.

\section{Results}

The study population consisted of 15 patients, nine men and six women, ranging in age from 46 to 72 years (mean \pm standard deviation $62.6 \pm 7.6$ years). Demographic and clinical characteristics for each patient are presented in Table II, as are data concerning the surgical procedure. Endothelin levels were elevated throughout the surgical procedure with respect to normal values. As is apparent in Fig. 1 , right atrial endothelin levels were significantly higher immediately after cessation of $C P B$ versus values before aortic crossclamping $(n=15,11.1 \pm$ 3.1 vs $14.2 \pm 3.7 \mathrm{pg} / \mathrm{ml}, p=0.008$ ). This trend was seen in both groups (for group $\mathrm{A}[n=10], 11.5 \pm$ 2.1 vs $14.7 \pm 4.2 \mathrm{pg} / \mathrm{ml}, p=0.03$; for group $\mathrm{B}[n=$ $5], 10.4 \pm 4.7$ vs $13.2 \pm 2.7 \mathrm{pg} / \mathrm{ml}, p=0.13$ ). Endothelin levels in the proximal aorta, however, were not significantly higher immediately after cessation of $\mathrm{CPB}$ (group $\mathrm{A}[n=10] 11.5 \pm 2$ vs $11.9 \pm$ $2.2 \mathrm{pg} / \mathrm{ml}, p>0.5$; group B $[n=5] 8.6 \pm 1.5$ vs 10.9 $\pm 2.8 \mathrm{pg} / \mathrm{ml}, p=0.34 ;$ combined $[n=15] 10.5 \pm 2.3$ vs $11.6 \pm 2.4 \mathrm{pg} / \mathrm{ml}, p>0.5$ ). In addition, whereas right atrial endothelin levels were similar to proximal aortic endothelin levels before aortic crossclamping $(n=15,10.5 \pm 2.3$ vs $11.1 \pm 3.1 \mathrm{pg} / \mathrm{ml}$, $p>0.5)$, they were significantly higher after cessation of CPB $(n=15,11.6 \pm 2.4$ vs $14.2 \pm 3.7 \mathrm{pg} / \mathrm{ml}$, $p=0.04)$, indicating increased secretion and production of endothelins in vasculature or organs distal to the proximal aorta. In the five patients belonging to group $\mathrm{B}$, coronary sinus levels of endothelins obtained during CPB tended to decline temporarily with ensuing recovery $(11.1 \pm 2.1 \mathrm{pg} / \mathrm{ml}$ before aortic crossclamping $7.9 \pm 1.91$ minute after release of aortic crossclamping, and $9.9 \pm 2.1 \mathrm{pg} / \mathrm{ml}$ after release of partial aortic crossclamping, $p=$ 0.06; Fig. 2). At the same times, endothelin levels in the proximal aorta tended to rise immediately after release of aortic crossclamping and then returned to precrossclamp values $(8.6 \pm 1.5,12.5 \pm 3.5$, and, $10.2 \pm 2.4 \mathrm{pg} / \mathrm{ml}$, respectively, $p=0.06$ ).

\section{Discussion}

Previous studies of ET levels during CABG. Previous studies have reported increased arterial endothelin levels in the course of CABG in human beings. ${ }^{12-15}$ Although Hynynen and coworkers ${ }^{15}$ proposed that elevated endothelin levels during $\mathrm{CABG}$ reflect surgical stress and catecholamine release, Knothe and colleagues ${ }^{13}$ found that arterial endothelin levels did not correlate with systemic hemodynamic or endocrinologic parameters (including catecholamine levels). None of the studies examined whether the heart contributed to the elevation in circulating plasma endothelin levels. To this end, we measured arterial, mixed venous, and coronary sinus endothelin levels during $\mathrm{CABG}$ in human beings. Moreover, to avoid any effects of hemodynamic instability on endothelin levels, we enrolled only patients with stable hemodynamic status before and during the surgical procedure (as reflected by monitored heart rate, blood pressure, urine output, and blood gas values). 


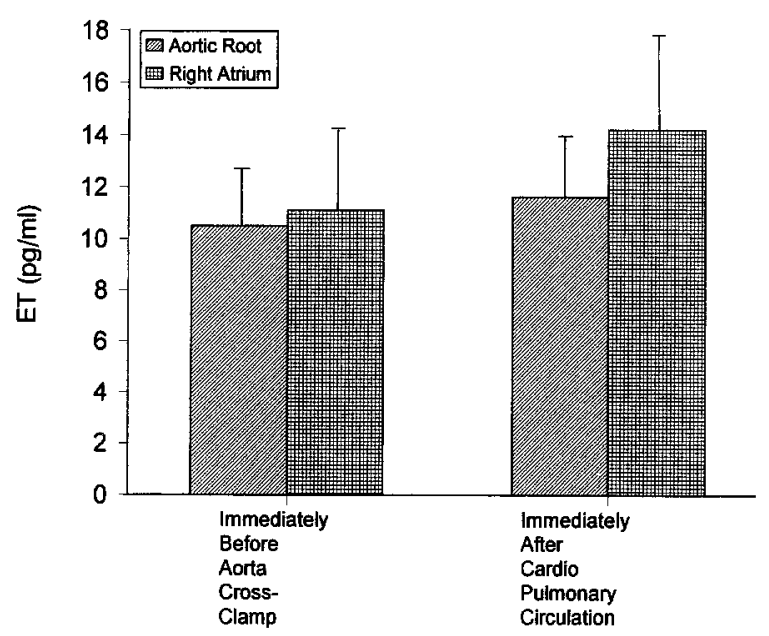

Fig. 1. Mean right atrial and proximal aortic levels of endothelins $(E T)$ in patients (groups A and B combined, $n=15$ ) immediately before aortic crossclamping and after cessation of cardio-pulmonary bypass circulation. (See text for statistical analysis.)

Main finding of study. The main finding of this study was that circulating endothelin levels increase in the course of CABG. Right atrial endothelin levels were significantly elevated after cessation of $\mathrm{CPB}$, compared with values immediately before aortic crossclamping. Endothelin levels in the proximal aorta did not rise significantly. Coronary sinus levels of endothelins measured in five patients also did not rise during $\mathrm{CPB}$; rather, they tended to decline temporarily. We therefore conclude that the rises in right atrial endothelin levels reflect systemic production and secretion of endothelins, most probably by vasculature or organs distal to the proximal aorta, and is not the result of increased myocardial production and secretion of endothelins. The trend toward transient increases in proximal aortic endothelin levels immediately after release of aortic crossclamping most probably reflects washout of blood that partially perfused the lungs and accumulated in the heart during cardioplegia.

Our data demonstrate marked fluctuations in endothelin levels during CABG. Indeed, the disparities among different studies to date regarding the effect of myocardial ischemia and reperfusion on circulating endothelin levels ${ }^{11}$ may be partially explained by temporal differences in drawing of blood samples and differences in the source of the blood samples (arterial, venous, coronary sinus). We chose to obtain baseline endothelin levels for all patients immediately before aortic crossclamping (rather

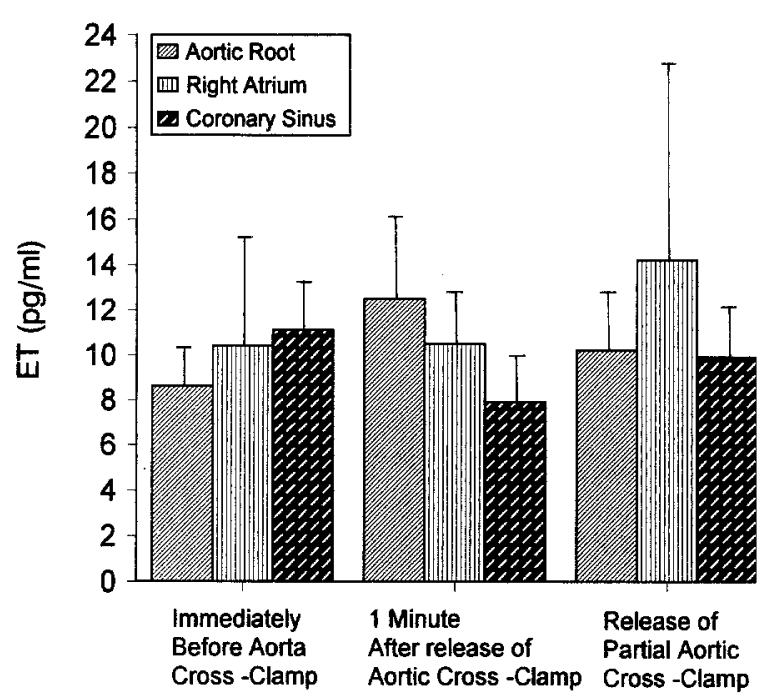

Fig. 2. Mean right atrial, proximal aortic, and coronary sinus levels of endothelins $(E T)$ in five patients of group B immediately before aortic crossclamping, 1 minute after release of aortic crossclamping, and after release of partial aortic crossclamping. (See text for statistical analysis.)

than before operation) to preclude possible effects on circulating endothelin levels of anesthesia, mechanical ventilation, and vascular injury during venous and arterial manipulation. Indeed, it is known that anesthesia and the surgical procedure themselves increase plasma endothelin levels. ${ }^{16,}{ }^{17}$ Similarly, we examined endothelin levels in all patients again immediately after cessation of CPB because previous studies showed that arterial endothelin levels are highest at this stage. ${ }^{12,13}$ As shown recently by Wang and coworkers ${ }^{27}$ and previously shown by others, ${ }^{11}$ endothelin levels rise only during the reperfusion period after experimental myocardial ischemia. For patients in group B, we therefore also measured coronary sinus levels of ET in two stages of $\mathrm{CPB}$, representing different stages of the reperfusion period.

Systemic versus local ET levels. Endothelins may be secreted into systemic circulation or abluminally to the interstitium. Indeed, it is claimed that abluminal secretion of endothelins is predominant, and that the major effect of endothelins is exerted at the paracrine level. ${ }^{11,28}$ For example, Wang and coworkers $^{27}$ reported a slight increase in coronary venous endothelin levels during the reperfusion period in pigs subjected to 45 minutes of coronary artery ligation. This rise was minute, however, compared with the dramatic rise in tissue content of 
endothelins in the ischemic myocardium. In contrast, Hiramatsu and associates ${ }^{29}$ recently showed that coronary sinus levels of endothelins are not altered during experimental CPB in lambs. In our study we measured only coronary sinus endothelin levels and not tissue levels, so we cannot determine unequivocally the effects of myocardial ischemia and reperfusion during $\mathrm{CABG}$ on myocardial endothelin levels. Our finding that coronary sinus endothelin levels are not elevated in the course of CABG (rather, they tend to decline temporarily), however, indicates that even if there is increased myocardial endothelin production and secretion, this does not affect systemic endothelin levels.

Implications regarding CABG. The clinical significance of elevated endothelin levels during $\mathrm{CABG}$ has yet to be determined. Although endothelins were thought to be merely a marker for stress (acute phase reactant), ${ }^{12,20}$ it is now reasonable to assume that they play an important role during $\mathrm{CABG}$ in light of the multitude of effects that they exert on the cardiovascular system. ${ }^{11}$ In the acute phase, endothelins may affect recovery from cardioplegic ischemia ${ }^{29}$ by attenuating microvascular flow in the reperfused bed. ${ }^{30}$ Because they are potent vasoconstrictors, ${ }^{1}$ they may also be at least partially responsible for the phenomenon of acute hypertension in the immediate postoperative period after CABG. ${ }^{31}$ Indeed, Boldt and colleagues ${ }^{14}$ recently showed that administration of angiotensinconverting enzyme inhibitors to patients undergoing heart operations reduces mean arterial pressure significantly during operation; this reduction occurs concomitantly with an attenuation of a rise in plasma endothelin levels. Moreover, the vasoconstrictive properties of endothelins may account for spasm of arterial grafts, thus compromising both acute blood flow and subsequent patency. ${ }^{32}$ In the long run, the effects of endothelins as potent promotors of vascular smooth muscle proliferation ${ }^{33-35}$ and intimal hyperplasia after vascular injury ${ }^{36}$ may contribute to the process of venous and arterial graft stenosis. As mentioned previously the local effects of endothelins may be of greater importance than their systemic effects. Myocardial production and secretion of endothelins during CABG thus might also have profound acute and long-term effects. With the recent introduction of novel therapeutic strategies designed to attenuate endothelin levels or activity (for example, endothelin-receptor antagonists ${ }^{37}$ ), it might be possible to prevent some of these shortand long-term complications.
Although this study was not designed to compare cardioplegic protocols, our data suggests that both cardioplegic protocols are associated with similar circulating endothelin levels and with the same fluctuation trends in endothelin levels. Because of the small number of patients in each group, however, further research is warranted to compare endothelin levels with different cardioplegic protocols.

Conclusion. This study shows that systemic endothelin levels are elevated during $\mathrm{CABG}$ and suggests that these changes reflect increased systemic, rather than myocardial, production and secretion of endothelins. Moreover, although myocardial endothelin levels may rise during $\mathrm{CABG}$ as a result of increased myocardial production and secretion, these changes are confined to the heart and may not have an effect on systemic endothelin levels.

\section{REFERENCES}

1. Yanagisawa M, Kurihara H, Kimura S, Tomobe Y, Kobayashi M, Mitsui $\mathrm{Y}$, et al. A novel potent vasoconstrictor peptide produced by vascular endothelial cells. Nature 1988; 332:411-5.

2. Inoue A, Yanagisawa M, Kimura S, Kasuya Y, Miyauchi T, Goto $\mathrm{K}$, et al. The human endothelin family: three structurally and pharmacologically distinct isopeptides predicted by three separate genes. Proc Natl Acad Sci U S A 1989;86: 2863-7.

3. Ehrenreich H, Anderson RW, Fox CH, Rieckmann P, Hoffman GS, Travis WD, et al. Endothelins, peptides with potent vasoactive properties, are produced by human macrophages. J Exp Med 1990;172:1741-8.

4. Ehrenreich H, Burd PR, Rottem M, Hültner L, Hylton JB, Garfield M, et al. Endothelins belong to the assortment of mast cell-derived and mast cell-bound cytokines. New Biol 1992;4:147-56.

5. Sessa WC, Kaw S, Hecker M, Vane JR. The biosynthesis of endothelin-1 by human polymorphonuclear leukocytes. Biochem Biophys Res Commun 1991;174:613-8.

6. Resink TJ, Hahn AW, Scott-Burden T, Powell J, Weber E, Buhler FR. Inducible endothelin mRNA expression and peptide secretion in cultured human vascular smooth muscle cells. Biochem Biophys Res Commun 1990;168:1303-10.

7. Giaid A, Yanagisawa M, Langleben D, Michel RP, Levy R, Shennib H, et al. Expression of endothelin-1 in the lungs of patients with pulmonary hypertension. N Engl J Med 1993; 328:1732-9.

8. Cybulsky AV, Stewart DJ, Cybulsky MI. Glomerular epithelial cells produce endothelin-1. J Am Soc Nephrol 1993;3: 1398-404.

9. Suzuki T, Kumazaki T, Mitsui Y. Endothelin-1 is produced and secreted by neonatal rat cardiac myocytes in vitro. Biochem Biophys Res Commun 1993;191:823-30.

10. Hemsen A, Franco-Cereceda A, Matran R, Rudehill A, Lundberg JM. Occurence, specific binding sites and functional effects of endothelin in human cardiopulmonary tissue. Eur J Pharmacol 1990;191:319-28. 
11. Hasdai D, Kornowski R, Battler A. Endothelin and myocardial ischemia. Cardiovasc Drugs Ther 1994;8:589-99.

12. Hynynen M, Saijonmaa O, Tikkanen I, Heinonen J, Fyhrquist $F$. Increased plasma endothelin immunoreactivity during cardiopulmonary bypass: a preliminary observation. $\mathbf{J}$ Thorac Cardiovasc Surg 1992;103:1024-5.

13. Knothe CH, Boldt J, Zickmann B, Ballesteros M, Dapper F, Hempelmann G. Endothelin plasma levels in old and young patients during open heart surgery: correlations to cardiopulmonary and endocrinology parameters. J Cardiovasc Pharmacol 1992;20:664-70.

14. Boldt J, Schindler E, Harter K, Gorlach G, Hempelmann G. Influence of intravenous administration of angiotensin-converting enzyme inhibitor enalaprilat on cardiovascular mediators in cardiac surgery patients. Anesth Analg 1995;80: 480-5.

15. Ray SG, McMurray JJ, Morton JJ, Dargie HJ. Circulating endothelin is not extracted by the pulmonary circulation in man. Chest 1992;102:1143-4.

16. Hirata $Y$, Ando K. Plasma endothelin levels during surgery (letter). N Engl J Med 1989;321:1686.

17. Onizuka M, Miyauchi T, Mitsui K, Suzuki K, Veno H, Goto K, et al. Plasma levels of endothelin- 1 and thrombin-antithrombin III complex in patients undergoing open chest operations [letter]. J Thorac Cardiovasc Surg 1993;105:559-60.

18. Velasco CE, Yanagisawa M, Williamson JL, Triana JF. Local endothelin-I production in the ischemic myocardium (abstract). Circulation 1993;88(4 Pt 2):I544.

19. Tønnessen T, Giaid A, Naess PA, Yanagisawa M, Christensen G. Endothelin-1 is synthesized and produced by ischemic cardiomyocytes (abstract). Circulation 1994;90(4 Pt 2): $\mathrm{I} 426$.

20. Miyauchi T, Yanagisawa M, Tomizawa T, Sugishita Y, Suzuki N, Fujino N, et al. Increased plasma concentrations of endothelin-1 and big endothelin-1 in acute myocardial infarction [letter]. Lancet 1989;2:53-4.

21. Rodheffer RJ, Lerman A, Heublein DM, Burnett JC Jr. Increased plasma concentrations of endothelin in congestive heart failure in humans. Mayo Clin Proc 1992;67:719-24.

22. Moore K, Wendon J, Frazer M, Karani J, Williams R, Badr $\mathrm{K}$. Plasma endothelin immunoreactivity in liver disease and the hepatorenal syndrome. N Eng1 J Med 1992;327:1774-8.

23. Tomita K, Ujie K, Nakanishi T, Tomura S, Matsuda O, Ando $\mathrm{K}$, et al. Plasma endothelin levels in patients with acute renal failure [letter]. N Engl J Med 1989;321:1127.

24. Yamane K, Kashiwagi H, Suzuki N, Miyauchi T, Yanagisawa $\mathrm{M}$, Goto $\mathrm{K}$, et al. Elevated plasma levels of endothelin-1 in systemic sclerosis [letter]. Arthritis Rheum 1991;34:243-4.
25. Stewart DJ, Levy RD, Cernacek P, Langleben D. Increased plasma endothelin-1 levels in pulmonary hypertension: marker or mediator of disease? Ann Intern Med 1991;114: 464-9.

26. Saito Y, Nakao K, Mukoyama M, Imura H. Increased plasma endothelin levels in patients with essential hypertension [letter]. N Engl J Med 1990;322:205.

27. Wang QD, Hemsen A, Li XS, Lundberg JM, Uriuda Y, Pernow J. Local overflow and enhanced tissue content of endothelin following myocardial ischaemia and reperfusion in the pig: modulation by L-arginine. Cardiovasc Res 1995; 29:44-9.

28. Luscher TF, Boulanger CM, Dohi Y, Yang Z. Endotheliumderived contracting factors. Hypertension 1992;19:117-30.

29. Hiramatsu T, Forbess JM, Miura T, Roth SJ, Cioffi MA, Mayer JE. Effects of endothelin-1 and endothelin-A antagonist on recovery after hypothermic cardioplegic ischemia in neonatal lamb hearts. Circulation 1995;92:II400-4.

30. Velasco $C E$, Turner $M$, Inagami $T$, et al. Reperfusion enhances the local release of endothelin after regional myocardial ischemia. Am Heart J 1994;128:441-51.

31. Estafanous FG, Tarazi RC, Viljoen JF, El Tawil MY. Systemic hypertension following myocardial revascularization. Am Heart J 1973;85:732-8.

32. He GW, Yang CQ, Starr A. Overview of the nature of vasoconstriction in arterial grafts for coronary operations. Ann Thorac Surg 1995;59:676-83.

33. Weissberg PL, Witchell C, Davenport AP, Hesketh TR, Metcalfe JC. The endothelin peptides ET-1, ET-2, ET-3 and sarafotoxin $\mathrm{S} 6 \mathrm{~b}$ are co-mitogenic with platelet-derived growth factor for vascular smooth muscle cells. Atherosclerosis 1990;85:257-62.

34. Weber H, Webb ML, Serafino R, Taylor DS, Moreland S, Norman J, et al. Endothelin-1 and angiotensin-II stimulate delayed mitogenesis in cultured rat aortic smooth muscle cells: evidence for common signaling mechanisms. Mol Endocrinol 1994;8:148-58.

35. Alberts GF, Peifley KA, Johns A, Kleha JF, Winkles JA. Constitutive endothelin-1 overexpression promotes smooth muscle cell proliferation via an external autocrine loop. J Biol Chem 1994;269:10112-8.

36. Trachtenberg JD, Sun S, Choi ET, Callow AD, Ryan US. Effect of endothelin-1 infusion on the development of intimal hyperplasia after balloon catheter injury. J Cardiovasc Pharmacol 1993;22(Suppl 8):S355-9.

37. Luscher TF. Do we need endothelin antagonists? Cardiovasc Res 1993;8:2089-93. 